Yol.2 2Nn. I لanuari 2019

ISSN 2614-2775

e-ISSN 2621-8143

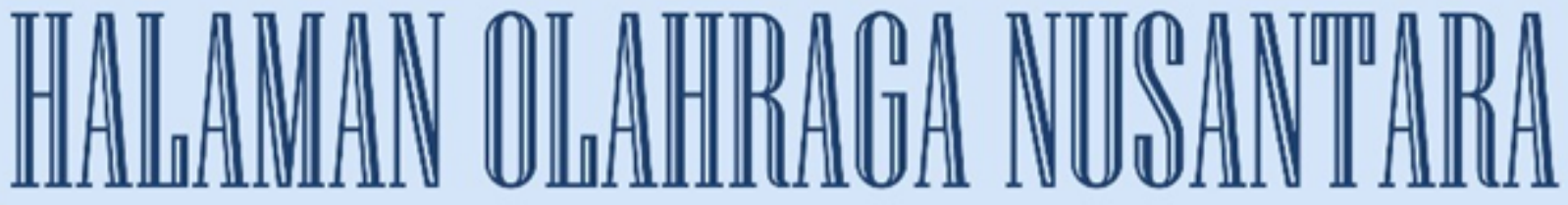

Surnal @lmu Xeolahragaan

Diterbitkan Oleh:

Program Studi Pendidikan Olahraga

Fakultas Keguruan dan Ilmu Pendidikan

Universitas PGRI Palembang

Jurnal

Volume Nomor Halaman Palembang ISSN/e-ISSN

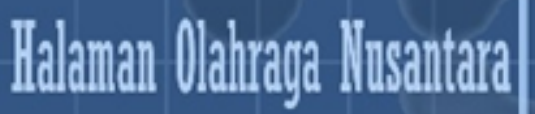

\begin{tabular}{l|l|l|l}
2 & 1 & $1-96$ & 2019
\end{tabular}




\section{Halaman Olahraga Nusantara}

Jurnal Ilmu Keolahragaan

Volume 2, Nomor 1, Januari 2019

Pelindung/Penasehat

Dr. H. Bukman Lian, M. M., M. Si.

Penanggung Jawab

Dr. Dessy Wardiah, M. Pd.

Ketua Dewan Redaksi

Farizal Imansyah, M. Pd.

Wakil Ketua Dewan Redaksi

Ilham Arvan Junaidi, M. Pd.

Sekretaris

Bayu Iswana, M. Pd.

Penyunting Pelaksana

Rafel Orlando, M. Pd.

Ardo Okilanda, M. Pd.

Daryono, M. Pd.

\section{Mitra Bestari}

Prof. Dr. A. Sofyan Hanif, M. Pd (Universitas Negeri Jakarta)

Dr. Sukirno (Universitas Sriwijaya)

Dr. Ronni Yenes, M. Pd (Universitas Negeri Padang)

Dr. Benny, M. Pd. (Universitas Negeri Makasar)

Dr. Putri Cicilia Kristina, M. Pd (Universitas PGRI Palembang)

\section{Tata Usaha}

M. Taheri Akbar, M. Pd.

Widya Handayani, S. Pd., M. Si.

Setting:

Dede Dwiansyah Putra, M. Pd.

Alamat Redaksi:

Prodi Pendidkan Olahraga Fakultas Keguruan Ilmu dan Pendidikan Universitas PGRI Palembang

Jl. Jendral A. Yani Lorong Gotong Royong 9/10 Ulu Palembang

Telp. 0711-510043, Fax. 0711-514782

e-mail jurnal: jurnalhonupgripalembang@gmail.com

e-mail : ardo.oku@univpgri-palembang.ac.id

website: univpgri-palembang.ac.id 
Halaman Olahraga Nusantara (Jurnal Ilmu Keolahragaan)

P-ISSN 2614-2775

Volume 2, No. 1, Januari 2019

E-ISSN 2621-8143

\section{DAFTAR ISI}

Hasil Penelitian

Halaman

Pengaruh Metode Rangkaian Bermain Terhadap Keterampilan Dasar Olahraga Panahan Siswa Ektrakulikuler Sit (Sekolah Islam Terpadu) Auladi Palembang

- Arisman

Penerapan Metode Bermain Dalam Meningkatkan Hasil Belajar Guling Depan (Forward Roll)

- Ruslan, M. Samsul Huda

Survei Tingkat Kesegaran Jasmani pada Peserta Ekstrakulikuler Sepakbola Di Sma Negeri 2 Oku

- Daryono

Kontribusi Daya Ledak Tungkai dan Keseimbangan Terhadap Kemampuan Lompat Jauh Murid Sd Negeri 139 Sinjai

- Adam Mappaompo

Survei Tingkat Kebugaran Jasmani Mahasiswa Pendidikan Olahraga Angkatan 2017 Stkip Pgri Bangkalan

- Heni Yuli Handayani .

Profil Delayed Onset Muscle Soreness (Doms) pada Mahasiswa Fik Unp Setelah Latihan Fisik

- Heru Syarli Lesmana

Perbedaan Pengaruh Latihan Menggunakan Karet dengan Menggunakan Dumbbell $1 \mathrm{Kg}$ Terhadap Kecepatan Pukulan Oi Tsuki

Chudan pada Atlet Karate Putra Perguruan Wadokai Dojo Sma Negeri 11 Medan Tahun 2017

- Pangondian Hotliber Purba $60-71$

Tinjauan Kondisi Fisik Atlet Sepakbola Kabupaten Kerinci Dalam

Rangka Persiapan Mengikuti Porprov Xxii Bungo Tebo 2018

- Palmizal, Wawan Junresti Daya, dan Sri Murniati

Aktivitas Jasmani dan Persepsi Gerak Anak Usia Dini

- Dian Pujianto 
Peningkatan Keterampilan Bermain Bolabasket Mahasiswa Melalui Latihan Aktifitas Maze Perkuliahan Permainan Bolabasket

- Ilham Arvan Junaidi dan Rury Rizhardy $88-96$ 


\title{
KONTRIBUSI DAYA LEDAK TUNGKAI DAN KESEIMBANGAN TERHADAP KEMAMPUAN LOMPAT JAUH MURID SD NEGERI 139 SINJAI
}

\author{
Oleh: Adam Mappaompo \\ (Dosen Universitas Negeri Makassar)
}

\begin{abstract}
Abstrak
Penelitian ini adalah jenis penelitian deskriptif yang menggunakan rancangan penelitian "korelasional". Penelitian ini bertujuan untuk mengetahui; (1) kontribusi daya ledak tungkai terhadap kemampuan lompat jauh murid SD Negeri 139 Sinjai; (2) kontribusi Keseimbangan terhadap kemampuan lompat jauh murid SD Negeri 139 Sinjai; (3) kontribusi daya ledak tungkai dan Keseimbangan secara bersama-sama terhadap kemampuan lompat jauh murid SD Negeri 139 Sinjai. Populasinya adalah seluruh murid putra SD Negeri 139 Sinjai. Sampel yang digunakan adalah sebanyak 40 orang murid. Teknik penentuan sampel adalah dengan pemilihan secara acak dengan cara undian (Simple Random Sampling). Teknik analisis data yang digunakan adalah analisis deskriptif, analisis koefisien korelasi, dan analisis regresi dan korelasi ganda $(R)$ pada taraf signifikan $\alpha=0,05$. Hasil penelitian menunjukkan bahwa; (1) Ada kontribusi yang signifikan daya ledak tungkai terhadap kemampuan lompat jauh murid SD Negeri 139 Sinjai, terbukti dengan nilai sebesar 34,3\%; (2) Ada kontribusi yang signifikan keseimbangan terhadap kemampuan lompat jauh murid SD Negeri 139 Sinjai, terbukti dengan nilai sebesar 27,7\%; (3) Ada kontribusi yang signifikan daya ledak tungkai dan keseimbangan secara bersama-sama terhadap kemampuan lompat jauh murid SD Negeri 139 Sinjai, terbukti dengan nilai sebesar 41,8\%;.
\end{abstract}

Kata Kunci: Daya Ledak Otot Tungkai, Keseimbangan, SD Negeri 139 Sinjai

\section{THE CONTRIBUTION OF EXPLOSIVE POWER A LIMB AND BALANCE OF THE ABILITY OF THE LONG JUMP 139 SINJAI PUBLIC ELEMENTARY SCHOOL STUDENTS}

\begin{abstract}
This research is the kind of research descriptive that uses design ' korelasional' research. This study aims to to know; (1) the contribution explosive power a limb of the ability of the long jump primary school students land 139 sinjai; ( 2 ) the contribution balance of the ability of the long jump primary school students land 139 sinjai; ( 3 ) the contribution explosive power a limb and balance together in the ability of the long jump primary school students land 139 sinjai. Its population is set is that an entire kind son of students in that particular month and private primary
\end{abstract}


schools state 139 sinjai. In the sample have used of these tests are as many as 40 two students .Dating techniques sample is with the selection at random by means of a raffle ( simple random sampling ). Analysis techniques the data used was a descriptive analysis, it is anticipated that analysis a correlation coefficient, and regression analysis and the correlation cup double this term $(r)$ the first significant $=0,05$. The research results show that; ( 1 there is a significant contribution explosive power a limb of the ability of the long jump primary school students land 139 sinjai, as evidenced by value of $34.3 \%$; ( 2 there is a significant contribution balance of the ability of the long jump primary school students land 139 sinjai, as evidenced by value of $27.7 \%$; ( 3 there is a significant contribution explosive power a limb and balance together in the ability of the long jump primary school students land 139 sinjai, as evidenced by value of 41,8\%;.

Keyword: Explosive Power a Limb, Balance, Sinjai State 139 Primary Schools

\section{A. PENDAHULUAN}

Atletik merupakan salah satu cabang olahraga wajib pada setiap materi pembelajaran disekolah, yang merupakan fondasi dari gerak dasar pada setiap mata pelajaran pendidikan olahraga karena dasar gerak seluruh cabang olahraga adalah atletik yang memilki gerakan dasar jalan, lari, lompat, dan lempar. Cabang olahraga atletik merupakan salah satu cabang olahraga yang telah memasyarakat dan digemari oleh seluruh lapisan masyarakat. Di samping itu cabang olahraga atletik merupakan cabang olahraga yang paling tua dan termasuk dari induk cabang lompat jauh merupakan salah satu nomor lompat dari cabang atletik. Lompat jauh merupakan suatu gerakan melompat menggunakan tumpuan satu kaki untuk mendarat sejauh jauhnya. Sasaran dan tujuan lompat jauh adalah untuk mencapai jarak lompatan sejauh mungkin kesebuah letak pendaratan atau bak lompat.

Dalam pelaksanaan lompat jauh terdapat empat rangkaian gerakan yang dimulai dari awalan sebagai langkah awal yang dilakukan dengan jarak ke papan (tumpuan), kemudian dilanjutkan sikap badan di udara untuk mencapai jarak lompatan yang maksimal dengan mendarat secara sempurna. Pelaksanaan teknik 
gerakan dalam lompat jauh merupakan satu kesatuan gerak yang tidak dipisahkan, untuk menghasilkan lompatan yang jauh sangat dipengaruhi oleh kecepatan lari awalan, kekuatan kaki tumpu, keseimbangan badan waktu melayang di udara dan kemampuan kelentukan tubuh pada saat mendarat.

Hampir disetiap cabang olahraga, unsur kondisi fisik seperti kecepatan, kekuatan, keseimbangan dinamis, daya tahan, keseimbangan dan koordinasi sangat diperlukan. Besar kecilnya kebutuhan akan unsur kondisi fisik berbeda-beda tergantung pada karakteristik dari cabang olahraganya. Demikian halnya pada lompat jauh, tiga unsur kondisi fisik yang sangat diperlukan adalah kecepatan, power otot tungkai dan keseimbangan dinamis. Untuk memperoleh suatu hasil yang optimal dalam lompat jauh, selain atlit harus memiliki daya ledak tungkai dan keseimbangan lompat jauh juga dipengaruhi oleh unsur daya ledak tungkai, dalam hal ini pelompat dapat melakukan lompatan dengan kuat jika didukung dengan daya ledak otot tungkai yang baik. Ada dua komponen yang tidak dapat dipisahkan dalam daya ledak tungkai yaitu kekuatan dan kecepatan yang dapat menghasilkan tenaga maksimal dalam waktu yang relatif singkat. Karenanya lompat jauh membutuhkan kekuatan dan kecepatan terutama pada saat melakukan tumpuan sehingga memungkinkan menghasilkan lompatan yang maksimal. Begitu pula halnya dengan keseimbangan juga mempunyai peranan yang tidak kalah pentingnya terhadap kemampuan lompat jauh. Keseimbangan Kondisi fisik lain yang dibutuhkan dalam lompat jauh adalah keseimbangan. Adapun yang dimaksud dengan keseimbangan adalah kemampuan seseorang menjaga posisi dan kestabilan badan terutama pada saat melakukan tolakan dan mempertahankan titik berat badan pada saat melayang di udara.

Mengacu dalam permasalahan nampaknya memiliki ruang lingkup yang luas sehingga dapat menyulitkan dalam pembahasan masalah dan penarikan kesimpulan, untuk itu masalah dalam penelitian ini hanya mencari kontribusi daya ledak tungkai dan keseimbangan terhadap kemampuan lompat jauh pada murid SD Negeri 139 Sinjai. 
Lompat jauh merupakan salah satu nomor dari cabang olahraga atletik, yang mana di dalam cabang atletik terdapat unsur - unsur gerak dasar manusia diantaranya berjalan, berlari, melompat, dan melempar. Menurut Aip Syaifuddin (1992) bahwa "lompat jauh adalah suatu bentuk gerakan melompat mengangkat kaki ke atas ke depan dalam upaya membawa titik berat badan selama mungkin (melayang di udara) yang dilakukan dengan cepat dan dengan jalan melakukan tolakan pada satu kaki untuk mencapai jarak yang sejauh - jauhnya“. Demikian pula yang dikemukakan Yusuf Adisamita (1992) bahwa "dalam perlombaan lompat jauh, seorang pelompat akan berusaha ke depan dengan bertumpu pada balok tumpuan sekuat - kuatnya untuk mendarat di bak lompat sejauh - jauhnya“.

Daya ledak tungkai biasa juga di sebut dengan istilah power yang sangat di butuhkan dalam berbagai cabang olahraga apalagi kalau olahraga itu menuntut aktifitas yang berat dan cepat atau kegiatan itu harus dilakukan dalam waktu singkat dengan beban yang berat. Untuk mampu melaksanakan aktifitas seperti itu di perlukan perpaduan antara kekuatan dan kecepatan otot yang di kerahkan secare bersama - sama dalam mengatasi tahanan beban dalam waktu yang relatif singkat.

Menurut Sajoto (988:58) bahwa:

"Power adalah kemampuan seseorang untuk melakukan kekuatan maksimum,dengan usahanya yang di kerahkan dalam waktu sependekpendeknya. “

Dari pendapat tersebut di atas menyebutkan dua unsur yang penting dalam power yaitu kekuatan otot dan kecepatan otot dalam menggerakkan tenaga maksimal untuk mengatasi tahanan, dengan demikian batasan power adalah kemampuan otot untuk mengerahkan kekuatan maksimal dalam waktu yang sangat cepat. Kekuatan merupakan dasar (basic) untuk menentukan power. Sebelum latihan power, orang sudah harus memiliki suatu tingkat kekuatan otot yang baik.Seperti yang di 
kemukakan oleh Ateng (1992:140) bahwa tenaga otot adalah kemampuan untuk melepaskan kekuatan otot secara maksimal dalam waktu yang singkat”.

Dari pendapat di atas dua unsur penting dalam power adalah kekuatan dan kecepatan otot dalam mengerahkan tenaga maksimal untuk mengatasi tahanan.Dengan demikian dapat di simpulkan bahwa power merupakan kemampuan otot yang di miliki oleh seseorang untuk mengerahkan kekuatan maksimal dalam waktu yang sangat cepat.

Keseimbangan merupakan kemampuan seseorang mempertahankan sistem tubuh, baik dalam posisi gerak dinamis yang mana keseimbangan juga merupakan hal yang sangat penting didalam melakukan suatu gerakan, karena dengan keseimbangan yang baik, maka seseorang mampu mengkoordinasikan gerakan-gerakan, dan dalam beberapa hal ketangkasan unsur kelincahan. Dengan demikian untuk menjaga keseimbangan dalam melakukan kegiatan jasmani, maka gerakan-gerakan yang dilakukan perlu dikoordinasikan dengan baik sebagai usaha untuk mengontrol semua gerakan.

Menurut Muchammad sajoto (1988:58) tentang kemampuan mengatasi titik berat berat badan yang lebih dikenal dengan istilah keseimbangan bahwa:

"Keseimbangan atau balance adalah kemampuan seseorang mengendalikan organ-organ syaraf ototnya selama melakukan gerakan-gerakan yang cepat dengan perubahan letak titik berat badan yang cepat pula baik dalam keadaan statis maupun lebih-lebih dalam keadaan gerak dinamis."

Lebih lanjut Harsono (1988:223) mengemukakan bahwa keseimbangan atau balance adalah "Kemampuan untuk mempertahankan sistem neuromuscular kita dalam kondisi statis, atau mengontrol sistem neuromuscular tersebut dalam suatu posisi atau sikap yang efesien selagi kita bergerak".

Adapun keseimbangan terbagi menjadi dua jenis, menurut Muchammad Sajoto (1988:54) yaitu: 
1. Keseimbangan statis adalah kemampuan tubuh dalam mempertahankan keseimbangan dalam posisi tetap.

2. Keseimbangan dinamis adalah kemampuan tubuh mempertahankan keseimbangan pada waktu melakukan gerakan dari suatu posisi ke posisi yang lain.

Dari berbagai pengertian tentang keseimbangan di atas, maka dapat dikatakan bahwa keseimbangan merupakan kemampuan seseorang mengendalikan organ-organ syaraf otot untuk menahan beban atau tahanan yang dilakukan di dalam beraktivitas baik secara statis maupun dinamis.

\section{B. METODOLOGI PENELITIAN}

Metode atau cara yang digunakan dalam penelitian ini adalah metode penelitian "Deskriptif' dengan teknik korelasi, yaitu mencari hubungan antara variabel yang satu dengan variabel lainnya. Seperti yang dikatakan Sukmadinata, (2006:73) bahwa "Penelitian deskriptif tidak memberikan perlakuan, manipulasi atau pengubahan pada variabel-variabel bebas, tetapi menggambarkan suatu kondisi apa adanya". Adapun Rancangan/desain penelitian yang digunakan adalah "Model Korelasional". Data yang terkumpul melalui tes masih merupakan data kasar. Data tersebut selanjutnya dianalisis dengan menggunakan uji statistik korelasional dengan bantuan paket SPSS dalam komputer. Analisis yang dimaksud dalam penelitian ini adalah analisis deskriptif untuk menggambarkan data apa adanya dan analisis infrensial untuk menguji hipotesis dengan menggunakan analisis korelasi sederhana. Sebelum melakukan analisis korelasi terlebih dahulu dilakukan analisis normalitas dengan menggunakan Kolmogorov Smirnov (KS-Z) dan program SPSS.

\section{HASIL PENELITIAN DAN PEMBAHASAN}

Untuk mendapatkan gambaran umum data suatu penelitian maka digunakanlah analisis data deskriptif. Analisis deskriptif dilakukan terhadap daya ledak tungkai dan keseimbangan dengan kemampuan lompat jauh murid SD Negeri 
139 Sinjai . Hal ini dimaksudkan untuk memberi makna pada hasil analisis yang telah dilakukan. Hasil analisis deskriptif data tersebut dapat dilihat pada tabel 1.

\begin{tabular}{cccc}
\hline Nilai Statistik & $\begin{array}{c}\text { daya ledak } \\
\text { tungkai }\end{array}$ & keseimbangan & $\begin{array}{c}\text { Kemampuan } \\
\text { lompat jauh }\end{array}$ \\
\hline $\mathrm{N}$ & 40 & 40 & 40 \\
Mean & 1,3712 & 80,30 & 2,7520 \\
SD & 0,12668 & 5,262 & 0,27300 \\
Varians & 0.016 & 27,690 & 0,050 \\
Range & 0,46 & 0,22 & 0,90 \\
Minimum & 1,12 & 57 & 2,29 \\
Maksimum & 1,56 & 79 & 3,19 \\
\hline
\end{tabular}

1. Daya ledak tungkai $\left(\mathrm{X}_{1}\right)$, diperoleh nilai rata-rata $($ mean $)=1,3712$, simpangan baku $($ standar deviasi $)=0,12668$, nilai terendah $($ minimum $)=1,12$ dan nilai tertinggi $($ maksimum $)=1,56$.

2. Keseimbangan $\left(\mathrm{X}_{2}\right)$, diperoleh nilai rata-rata (mean) $=80,30$, simpangan baku $($ standar deviasi $)=5,566$, nilai terendah $($ minimum $)=67$ dan nilai tertinggi $($ maksimum $)=80$.

3. Kemampuan Lompat jauh (Y), diperoleh nilai rata-rata $($ mean $)=2,7520$, simpangan baku (standar deviasi $)=0,22304$, nilai terendah $($ minimum $)=$ 2,29 dan nilai tertinggi (maksimum) $=3,19$.

Salah Salah satu persyaratan yang harus dipenuhi agar statistik parametrik dapat digunakan dalam menganalisis data penelitian adalah data harus mengikuti sebaran normal (berdistribusi normal). Untuk mengetahui apakah data daya ledak tungkai dan keseimbangan dengan kemampuan lompat jauh murid SD Negeri 139 Sinjai berdistribusi normal, maka dilakukan uji normalitas data dengan menggunakan uji Kolmogorov Smirnov. Hasil uji normalitas dapat dilihat pada Tabel 2. berikut ini: 


\begin{tabular}{cccc}
\hline Nilai Statistik & $\begin{array}{c}\text { Daya ledak } \\
\text { tungkai }\end{array}$ & Keseimbangan & $\begin{array}{c}\text { Kemampuan } \\
\text { Lompat jauh }\end{array}$ \\
\hline $\mathrm{N}$ & 40 & 40 & 40 \\
KS-Z & 0,807 & 0,801 & 0,682 \\
As.Sig & 0,533 & 0,543 & 0,741 \\
\hline
\end{tabular}

Berdasarkan Tabel 2 di atas, maka pengujian normalitas data dengan menggunakan uji Kolmogrov-Smirnov (KS-Z) menunjukkan hasil sebagai berikut:

1. Untuk data daya ledak tungkai, diperoleh nilai $\mathrm{KS}-\mathrm{Z}=0,807$ $(\mathrm{P}=0,533>\alpha 0,05)$, sehingga dapat disimpulkan bahwa data daya ledak tungkai mengikuti sebaran normal atau berdistribusi normal.

2. Untuk data keseimbangan, diperoleh nilai $\mathrm{KS}-\mathrm{Z}=0,801(\mathrm{P}=$ $0,543>\alpha 0,05)$, sehingga dapat disimpulkan bahwa data keseimbangan mengikuti sebaran normal atau berdistribusi normal.

3. Untuk data kemampuan lompat jauh, diperoleh nilai $\mathrm{KS}-\mathrm{Z}=$ 0,682 $(\mathrm{P}=0,742>\alpha 0,05)$, sehingga dapat disimpulkan bahwa data kemampuan lompat jauh mengikuti sebaran normal atau berdistribusi normal.

Berdasarkan table analisis regresi bahwa besarnya kontribusi variable daya ledak tungkai $\left(\mathrm{X}_{1}\right)$ terhadap kemampuan lompat jauh $(\mathrm{Y})$ yang dihitung dengan koefisien regresi adalah 0,586 dengan nilai koefisien determinasi Rsquare sebesar 0,343 atau 34,3\%. Hal ini menunjukkan ada kontribusi yang signifikan antara daya ledak tungkai terhadap kemampuan lompat jauh. Sedangkan tingkat signifikan koefisien regresi dua sisi ( 2-tailed ) dari output (diukur dari probabilitas) menghasilkan angka 0,000 atau 0 . Karena nilai probabilitas jauh di bawah $\alpha 0,05$, maka kontribusi keseimbangan terhadap kemampuan lompat jauh signifikan sebesar $34,3 \%$. Dari hasil analisis data dengan menggunakan uji regresi, diperoleh nilai $r=$ 0,586 $\left(\mathrm{P}_{\text {value }}<\alpha 0,05\right)$, maka $\mathrm{H}_{0}$ ditolak dan $\mathrm{H}_{1}$ diterima. Hal ini berarti, ada kontribusi yang signifikan keseimbangan terhadap kemampuan lompat jauh Murid SD Negeri 139 Sinjai. Hal ini mengandung makna bahwa, apabila seorang murid 
memiliki daya ledak tungkai yang baik, maka akan diikuti terhadap kemampuan lompat jauh yang baik pula.

Berdasarkan table analisis regresi bahwa besarnya kontribusi variable keseimbangan $\left(\mathrm{X}_{2}\right)$ terhadap kemampuan lompat jauh $(\mathrm{Y})$ yang dihitung dengan koefisien regresi adalah 0,526 dengan nilai koefisien determinasi Rsquare sebesar 0,277 atau $27,7 \%$. Hal ini menunjukkan ada kontribusi yang signifikan antara keseimbangan terhadap kemampuan lompat jauh. Sedangkan tingkat signifikan koefisien regresi dua sisi ( 2-tailed ) dari output (diukur dari probabilitas) menghasilkan angka 0,000 atau 0 . Karena nilai probabilitas jauh di bawah $\alpha 0,05$, maka kontribusi keseimbangan terhadap kemampuan lompat jauh signifikan sebesar $27,7 \%$.

Dari hasil analisis data dengan menggunakan uji regresi, diperoleh nilai $\mathrm{r}=$ 0,526 ( $\left.\mathrm{P}_{\text {value }}<\alpha 0,05\right)$, maka $\mathrm{H}_{0}$ ditolak dan $\mathrm{H}_{1}$ diterima. Hal ini berarti, ada kontribusi yang signifikan keseimbangan terhadap kemampuan lompat jauh Murid SD Negeri 139 Sinjai. Hal ini mengandung makna bahwa, apabila seorang murid memiliki daya ledak tungkai yang baik, maka akan diikuti terhadap kemampuan lompat jauh yang baik puladiikuti dengan kemampuan lompat jauh yang baik pula.

Dari hasil analisis data dengan menggunakan uji regresi, diperoleh nilai $\mathrm{r}$ hitung $(\mathrm{R})=0,647$, nilai $\mathrm{R}$ square $\left(\mathrm{R}^{2}\right)$ sebesar $0,418 \mathrm{R}$ square dapat disebut koefisien determinasi yang dalam hal ini berarti $41,8 \%$, kontribusi yang signifikan antara variable daya ledak tungkai dan keseimbangan, dengan kemampuan lompat jauh Murid SD 139 Sinjai sedangkan sisanya 37,2\% dapat dijelaskan oleh sebab-sebab lain yang tidak diteliti pada penelitian ini. Nilai R square berkisar 0 sampai 1, dengan catatan semakin kecil nilai $\mathrm{R}$ square, semakin lemah kontribusi ketiga variable tersebut. Jadi, kontribusi secara bersama-sama variable daya ledak tungkai dan keseimbangan dengan kemampuan lompat jauh.

Dari table uji anova atau $F$ tes, ternyata didapat $F$ hitung sebesar 13,314 dengan tingkat signifikan 0,000 karena nilai probabilitas $(0,000)$ jauh lebih kecil dari 0,05, 
maka model regresi dapat dipaki untuk memperediksikan kemampuan lompat jauh. Untuk menguji signifikansi variabel daya ledak tungkai dan keseimbangan, secara bersama-sama dengan kemampuan lompat jauh. Hal ini mengandung makna bahwa, apabila seorang murid memiliki daya ledak tungkai dan keseimbangan, yang baik, maka akan diikuti dengan kemampuan lompat jauh yang baik pula.

\section{KESIMPULAN DAN SARAN}

Berdasarkan hasil analisis data dan pembahasannya, maka hasil penelitian ini disimpulkan sebagai berikut: Daya ledak tungkai cukup memberikan kontribusi terhadap kemampuan lompat jauh Murid SD 139 Sinjai. Keseimbangan cukup memberikan kontribusi terhadap kemampuan lompat jauh Murid SD 139 Sinjai. Daya ledak tungkai dan keseimbangan cukup memberikan kontribusi secara bersama-sama terhadap kemampuan lompat jauh Murid SD 139 Sinjai. Adapun saran yang dikemukakan dalam penelitian ini adalah, kepada para atlit lompat jauh, selalu memperhatikan dan melatih diri dan membekali diri mengenai pengetahuan tentang pentingnya mengembangkan kemampuan fisik seperti daya ledak tungkai dan keseimbangan. Bagi mahasiswa yang berminat melakukan penelitian lebih lanjut, disarankan agara melibatkan variabel-variabel lain yang relevan terhadap penelitian ini serta terhadap populasi dan sampel yang lebih luas.

\section{DAFTAR PUSTAKA}

Ateng, Abdul Kadir. 1992. Asas dan landasan pendidikan jasmani. Jakarta: Dirjen Dikti Depdikbud.

Hadi, Sutrisno. 1993. Statistik. Yogyakarta: Andi Offset

Halim, Nur Ichsan. 2004. Tes dan Pengukuran Kesegaran Jasmani. Makassar: Sum Press.

Harsono. 1988. Coaching dan aspek - aspek psikologis dalam coaching. Jakarta : Dirjen Dikti P2LPTK Depdikbud. 
IAAF. 1994 . Teknik - teknik atletik dan Tahap - tahap Mengajarkan. Jakarta : PASI. Jensen, C.R, Gorden W, and Begester, BL. 1983. Aplied Kinesiology and Boimekanic. New York: Mc Grow Hill Book Company.

Jhonson, Barry L . \& Nelson, Jack K. 1986. Practical Measurements for Evaluation in Physical Education. New York : Macmittan Publishing Company.

Jonath ,U.Haag ,E.Krempel , R. 1987 : atletik 1. Jakarta : Jaya Putera.

Jusuf, Soewandi. 1992 . Dasar - dasar dan Metode Latihan Kekuatan. Surabaya : Media Pendidikan.

Kosasih , Engkos. 1985. Olahraga Teknik dan Program Latihan. Jakarta : Akademi Presindo.

Sajoto ,Mochamad. 1988. Pembinaan Kondisi Fisik Dalam Olahraga. Jakarta : Dirjen Dikti P2LPTK Depdikbud.

Syarifuddin , Aip. 1992. Atletik. Jakarta : Dirjen Dikti Depdikbud.

Sugiyono. 2006. Statistik Untuk Penelitian. Alfabeta: Bandung.

Willmore, J.H. 1977. Atlhetic Training and Phisical Fitnees. Sydney: Allyn and Bacon Inc.

Yahya, M. Kasmad. 1994. Belajar Gerak. Makasar: FIK UNM. 


\section{GAYA SELINGKUNG}

1. Jurnal Halaman Olahraga Nusantara menerbitkan karya ilmiah dan hasil penelitian dalam seluruh kajian ilmu keolahragaan, baik pendidikan, kepelatihan, dan lainya dalam pengembangan teori dan konsep yang belum pernah dipublikasikan. Jurnal ini memuat (1) kumpulan informasi baru, (2) hasil objektif dari suatu kajian ilmu keolahragaan, dan (3) rekomendasi.

2. Penulisan naskah menggunakan bahasa Indonesia secara benar. Panjang naskah antara 7-20 halaman, kertas ukuran quarto, diketik 1,5 spasi, tipe huruf Times New Roman, ukuran huruf 12, margin atas dan kiri 4 cm, kanan dan bawah $3 \mathrm{~cm}$.

3. Naskah ditulis dengan sistematika dan ketentuan sebagai berikut.

a. Judul: ditulis dengan singkat, padat, terdiri dari 5-15 kata, dan menggunakan bahasa Indonesia, harus mencerminkan substansi keilmuan yang diuraikan pada batang tubuh artikel. Judul utama (main title) dan anak judul (subtitle) dipisahkan dengan dua titik. Judul artikel dicetak 15 mm dibawah tepi atas, dengan huruf capital-kecil tebal. Judul subbab peringkat 1 dicetak capital semua, rata tepi kiri, tebal, peringkat 2 dicetak capital kecil, rata tepi kiri, tebal; peringkat 3 dicetak kapital-kecil, rata tepi kiri, miring-tebal.

b. Nama penulis: Nama penulis artikel ditulis tanpa disertai gelar akademik atau gelar apapun. Nama lengkap dengan gelar akademik boleh ditulis disebelah bawah halaman pertama artikel. Nama lembaga tempat bekerja penulis juga dibuat sebagai catatan kaki dihalaman pertama. Jika lebih dari tiga penulis, hanya penulis utama saja yang dicantumkan dibawah judul; nama penulis lain ditulis dalam catatan kaki.

c. Abstrak artikel kajian ilmiah/ konseptual adalah ringkasan dari isi artikel yang dituangkan secara padat menggunakan bahasa Indonesia dan bahasa inggris. Abstrak hasil penelitian memuat masalah atau tujuan, metode, dan hasil penelitian. Abstrak terdiri dari 100-300 kata yang disusun dalam satu 
paragraph dengan format esei bukan enumeratif, dan diketik dengan spasi tunggal serta dengan format yang lebih sempit dari teks utama.

d. Kata Kunci terdiri dari 3-5 kata, yaitu istilah-istilah yang mewakili ide atau konsep dasar yang dibahas dalam penulisan karya ilmiah. Kata kunci lazimnya berupa kata dasar atau kata yang berdiri sendiri (tunggal) bukan rangkaian kata.

e. Naskah hasil penulisan ditulis dengan urutan (1) judul, (2) nama penulis, (3) abstrak, (4) kata kunci, (5) bagian pendahuluan yang harus di akhiri dengan rumusan singkat (1-2 kalimat) tentang hal-hal pokok yang akan dibahas dan tujuan dari pembahasan. Untuk artikel hasil penelitian berisi (a) rumusan masalah, (b) tujuan, dan (c) deskripsi singkat mengenai kerangka pemikiran dalam pendahuluan, (6) isi memuat (a) metode penelitian, (b) hasil penelitian, dan (c) pembahasan. (8) simpulan dan saran, (9) daftar pustaka.

f. Naskah diluar hasil penelitian ditulis dengan urutan (1) judul, (2) nama penulis, (3) abstrak, (4) kata kunci, (5) pendahuluan yang memuat latar belakang dan rumusan masalah, (6) isi, (7) simpulan, dan (8) daftar pustaka.

g. Table dan gambar/ bagan di usahakan dicetak dalam satu halaman, nomor dan judul table dan gambar dicetak di atas table dengan huruf tebal. Isi dalam table dicetak dengan huruf normal (tidak tebal). Table hanya menggunakan garis horizontal (horizontal border)

h. Penulisan daftar pustaka

1) Buku ditulis dengan urutan: (a) nama akhir, (b) koma, (c) nama depan penulis, (d) titik, (e) tahun penerbitan, (f) titik, (g) judul buku dalam huruf miring, (h) titik, (i) edisi jika ada, (j) titik, (k) kota penerbitan, (l) titik dua, (m) nama penerbit, dan (n) titik.

2) Artikel ditulis dengan urutan: (a) nama akhir, (b) koma, (c) nama depan penulis, (d) titik, (e) tahun penerbitan, (f) titik, (g) tanda petik dua, (h) judul artikel, (i) titik, (j) tanda petik tutup, (k) nama jurnal dalam cetak miring, (l) volume, (m) nomor, dan (n) titik. Apabila artikel diterbitkan 
disuatu buku, tulis kata "dalam" sebelum nama editor buku tersebut, dan buku harus ditulis didalam daftar pustaka.

3) Skripsi, thesis, atau disertasi ditulis dengan urutan: (a) nama akhir, (b) koma, (c) nama depan penulis, (d) titik, (e) tahun, (f) titik, (g) judul dalam huruf miring, (h) skripsi/thesis/disertasi pada (nama perguruan tinggi yang bersangkutan), (i) nama kota, (j) titik dua, (k) tulisan "tidak diterbitkan", dan (1) titik. 